A N NALES

UNIVERSITATIS MARIAE CURIE-SKŁODOWSKA LUBLIN - POLONIA

VOL. XXIX, 3

SECTIO J

2016

Maria Curie-Skłodowska University. Faculty of Pedagogy and Psychology

\author{
${ }^{*}$ KALINA MARIA $Ł U K A S I E W I C Z,{ }^{* *}$ BARBARA GAWDA \\ *kalina.lukasiewicz@gmail.com,**basia.gawda@poczta.umcs.lublin.pl
}

\title{
The Personality Predictors for the Literary Creativity in Early Adulthood
}

Osobowościowe predyktory twórczości literackiej w okresie wczesnej dorosłości

\begin{abstract}
SUMMARY
The aim of the current study is showing the personality predictors for the literary creativity in early adulthood. The material from 357 participants was analyzed. About $50 \%$ of them undertook the literary creativity, they write poems, stories, novels. Two personality questionnaires (ACL, KANHIII) were used to assess personality traits potentially associated with creative personality. Logistic regression was used to find the personality predictors. The dependent variable was binary coded: literary activity vs lack of literary activity; the independent variables were Potency, Assertiveness, Sociability, Individuality (ACL) and Conformity-Non-conformity (KANH). Results showed that the significant predictors for the literary creativity in women are Non-conformity and Individuality, low level of Potency, low level of Assertiveness. The significant predictors for the literary creativity in men are high level of Conformity and high level of Assertiveness.
\end{abstract}

Keywords: personality; creativity; literary creativity

\section{INTRODUCTION}

The research concerning personality of creative persons has been conducted in two streams. The first one was presented by researchers who focused on seeking personality mechanisms as superior regulators of creativity (Nęcka 2012). One of the first theories in this stream was the psychopathological creativity theory implying the close connections between creativity and personality disorders 
(Popek 2001, 2010). Other concepts from the same stream are the psychodynamic theory implying that creativity stems from the sublimation of sexual energy, and the humanistic psychology which holds that creativity is a result of pursuing selfactualization (Nęcka 2012).

The second stream of research on the creator's personality is focused on seeking traits of personality which correlate with creativity measured with the use of creative thinking tests. Currently, the most well-known personality model is the Costa and McCrae's Big Five (NEO) (McCrae \& Costa 2008). The researchers confirmed the relationships between creativity and selected dimensions of personality from the Big Five model. Divergent thinking proved to be connected with Openness to Experience and Extraversion (positive correlations) and Agreeableness (negative correlations) (Batey et al. 2009, Chamorro-Premuzic \& Reichenbacher 2008, Furnham \& Bachtiar 2008). In the research using inventories of creative achievements, the relationship between creativity, Extraversion and Openness to Experience has also been shown (Batey et al. 2010, Furnham \& Bachtiar 2008). The researches carried out by Kaufman and his associates show that Openness to Experience and Extraversion are related to the level of creative achievement only in terms of art, whereas the opposite pole of openness - intellect - is related to the level of creative achievement in terms of science (Kaufman et al. 2015).

\section{PERSONALITY AND CREATIVITY}

The most recent concept of personality based on the Big Five is the six-factor HEXACO model (Strus \& Cieciuch 2014) which contains an additional factor: Honesty-Humility. This factor expresses moral aspects of personality (Ashton \& Lee 2001, 2005, 2007). The HEXACO model comprises the factors which have been redefined (Lee \& Ashton 2004). The research based on the HEXACO model showed that the predictors for creativity are Openness to Experience and Extraversion (positive correlation) and also Honesty-Humility (negative correlation) (Nusbaum \& Silvia 2011, Silvia et al. 2011). The researchers have not observed any relationship between creativity and Agreeableness which is opposite to the findings based on the Big Five (Silvia et al. 2011).

In search of higher-order personality factors, Digman presented research suggesting there are two meta-traits generated from the Big Five model. The first meta-factor is comprised of Agreeableness, Conscientiousness and Emotional Stability. Digman proposed to name it Alpha. The second factor called by Digman - Beta - is comprised of Extraversion and Intellect/Openness (Digman 1997). DeYoung, Peterson and Higgins (2002) replicated the two meta-traits introduced by Digman, however, they called these factors differently - the factor Alpha (initially called socialisation) is named stability, and the factor Beta (previously de- 
scribed as personal development) - plasticity. Stability concerns stability of functioning in emotional, social and motivational spheres, and it is connected with the serotonin system. Plasticity expresses cognitive and behavioural flexibility, tendency to explore and voluntary engagement in new experiences (DeYoung et al. 2002). This model has been named the Huge Two. The research by Silvia et al. has shown that plasticity is more strongly correlated with creativity than stability. Plasticity correlated positively with divergent thinking fluency, everyday creativity, creative achievement, global creativity, hands-on creativity and interpersonal creativity. Stability is connected with everyday creativity, interpersonal creativity and science creativity (Silvia et al. 2009).

Nęcka (2012) created his own model of creative personality which aims to discover personality mechanisms of creativity in a synthetic way. In his opinion, creative personality might be described through three groups of traits: openness, independence and persistence. Openness is connected with easiness of absorbing new information, cognitive curiosity, aesthetic interests, plasticity and deep thinking. This trait is, to a great extent, connected also with preference for change, need for novelty, need for constant stimulation and new, extraordinary experiences. Independence is related to nonconformist attitude, low susceptibility to social influence, following one's own standards and set goals, sometimes challenging norms, declaring unconventional views and expressing them, which is also connected with rebelliousness. Nęcka also stresses the role of psychoticism which might be manifested in psychopathy, schizophrenia or creativity. Persistence of creative people is manifested in their readiness and ability to long-lasting effort and postponing gratification. Creative people also display the paradoxical structure of personality - on the one hand, they are able to stir autonomous motivation, on the other hand, high ambition, need for achievement and confirmation of self-worth are oftentimes characteristic of them (Nęcka 2012).

\section{PERSONALITY OF THE CREATIVE WRITER}

A lot of works tend to describe the traits of creative people with relation to their field of work. Popek stresses the fact that general abilities, understood as intellectual potential, are not the same as special abilities, characteristic of a given domain (Popek 2001). The thesis assuming that creativity is specific for a given domain has been confirmed in numerous researches (Baer et al. 2010; Han \& Marvin 2002; Kaufman 2012; Park et al. 2007; Piirto 1998; Plucker 1999; Silvia, Kaufman et al. 2009).

Still, there are not many researches concerning literary activity and creative writers, however, interest in this subject increases. Numerous studies showed the relationship between literary activity and mental disorders (Kaufman 2001; Kaufman \& Sexton 2006; Ludwig 1994, 1995). Researches show that creative 
writers often suffer from schizophrenia, mood disorder and more often commit suicide than representatives of other professions (Jamison 1996; Kaufman 2000, 2003; Kaufman \& Baer 2002; Kohanyi 2005; Nettle 2006; Preti \& Miotto 1999; Silvia \& Kaufman 2010). Piirto devoted many of her works to research on creative writers. She pointed out that writers have increased imaginative, intellectual and emotional excitability (Piirto 2002, 2010). She described characteristics of the creative writers. On the basis of research on creative people who write and children who have literary creativity, she presented 16 traits of these people: metaphorical thinking, visual imagination, openness to experience or readiness to play with ideas (Piirto 2004). Creative writers are characterized by independence and non-conformity. They value ethical and aesthetic aspects, maintain the state of constant curiosity and amazement. They can be described as people sensitive in terms of aesthetics, appreciating intellectual values and cognitive aspects (Piirto 2002). Furthermore, other research confirms that creative writers are characterized by high openness, they highly esteem intellectual values and esthetical experiences, and are also characterized by original perception (Greengross \& Miller 2009; Piirto 2002). Kaufman compared the journalism students' personality traits and literary talented students' personality traits, and he showed that literary talented students are characterized by higher level of neuroticism and openness to experience and lower level of conscientiousness (Kaufman 2002).

\section{METHOD}

\section{Research question}

The aim of the undertaken empirical research is to establish personality predictors for the literary activity in young adults. The following discussion will concern traits that are used by young artists to describe themselves as writers. If one wishes to find personality mechanism of creativity, one should build causeand-effect models, in which causes will be personality traits and effects - creative works (Nęcka 2012). Thus, in order to find personality predictors for undertaking literary activity by young adults, a model of logistic regression has been built. In this model, the dependent variable is the undertaking creative literary activity and the independent variables are personality traits. The main research issue will be to answer the question: Are personality factors the predictors for literary activity in young adults and - if so - in what way?

\section{Techniques and procedure}

1. The Adjective Check List ACL is a tool that contains 300 adjectives. A subject is to choose those which describe himself/herself. It measures selected per- 
sonality traits. ACL enables evaluation in 37 scales: thematic scales, needs scales, transactional analysis scales, creativity and intelligence scales and control scales. Factor analysis carried out on standardised results (T-scores) enabled the extraction of six higher-order factors:

- Potency - factor characterised by pursuing and being able to complete undertaken activities and set goals, accuracy and organisation in action, discipline in carrying out duties, efficiency, resourcefulness, firmness, goal-orientation and striving for success;

- Assertiveness - factor characterised by trusting oneself, self-confidence, willingness to attract attention, initiative, and on the other hand, frankness, not taking others into account, irritation in the case of facing obstacles, obstinacy, tendency to aggressive behaviour, need for authority, strong will, and high demands;

- Sociability - factor expresses sympathy, concern for others, easiness in establishing new contacts, patience, understanding, willingness to help others;

- Individuality - it is a factor connected with independence, non-conformity, unconventionality, liking of aesthetic experience, sensitivity in terms of aesthetics, openness and inventiveness;

- Dissatisfaction - this factor is connected with tendency to introspection, focus on oneself, anxiety and unrest;

- Sense of limitation - this factor is connected with high discipline, rigidness, conventionality and conservative views, observing regulations and recommendations, as well as submissiveness. In Polish research this factor was not recreated.

This technique has satisfying reliability and validity. It has norms on T-score for females and males (Martowska 2012).

2. The Questionnaire of Creative Behaviour KANH-III is a technique measuring the creative attitude defined as personality and cognitive characteristics. The revised version of KANH-III consists of 26 statements. The subjects use a 5 -step scale in order to assume an attitude towards the statements. They evaluate to what extent a given statement is true for them. This questionnaire enables the evaluation in 2 scales:

- Conformity-Non-conformity $(\mathrm{K}-\mathrm{N})$, expressing personality aspect of the creative attitude;

- Algorithmic behaviours-Heuristic behaviours, expressing the cognitive component of creative attitude. KANH-III is a valid and reliable tool. It has got the norms on T-score (Bernacka 2009). 
3. The short interview was conducted focused on the collecting the basic data such as age, sex, education, literary creativity, personal achievements in creative areas.

\section{Variables}

The independent variables in the model were: Potency, Assertiveness, Sociability, and Individuality (from the ACL), Conformity-Non-conformity (from $\mathrm{KANH}$ ). The dependent variable was binary coded, it was literary creativity vs. lack of literary creativity (data from the interview). Due to a failed attempt to recreate the factor Sense of limitation in Polish research (Martowska 2012), it has not been included in analyses. Due to the fact that Polish normalization had an ambiguous result, for each factor Cronbach's alpha reliability coefficient has been calculated (Table 1). The lowest reliability has been achieved by the factor Dissatisfaction $(\alpha=0.224)$, whereas the reliability of the remaining factors was satisfying - oscillating between 0.697 and 0.922 . Due to the low reliability, the factor Dissatisfaction has not been included in further analyses.

Table 1. List of the factors included in the model of regression analysis (with Cronbach's alpha)

\begin{tabular}{|l|l|c|c|c|}
\hline \multirow{2}{*}{ Factors } & \multicolumn{2}{c|}{ Components (scales) } & \multicolumn{3}{c|}{ Cronbach's alpha } \\
\cline { 3 - 5 } & & Women & Men & Total \\
\hline Potency & Ach, End, Ord, A, AC(-), A4 & 0.875 & 0.875 & 0.875 \\
\hline Assertiveness & Dom, Exh, Agg, Aba(-), S-Cn(-), FC & 0.920 & 0.927 & 0.922 \\
\hline Sociability & Fav, Nur, Aff, P-Adj, NP., A3 & 0.906 & 0.866 & 0.900 \\
\hline Individuality & Int, Aut, Cha, Def(-), Cps, A2 & 0.723 & 0.533 & 0.697 \\
\hline Dissatisfaction & No.Ckd, Unfav, Suc, Fem, CP & 0.250 & 0.115 & 0.224 \\
\hline
\end{tabular}

Source: Authors' own study based on Martowska (2012).

\section{Participants}

Data of 357 people, including 288 women and 69 men, was used for the purpose of further analysis. The subjects were between the ages of 18 and 29 $(\mathrm{M}=21.950 ; \mathrm{SD}=1.973)$. Most subjects were students $(73 \%) .24 \%$ of subjects were working people, $2 \%$ - school students and $1 \%$ - professionally inactive. The subjects came from different regions of Poland. $28 \%$ of them were residents of rural areas, $23 \%$ - town residents (town - up to 100,000 residents), and the remaining $49 \%$ were city residents (city - more than 100,000 residents). $51.5 \%$ of subjects were people literary active - they create different literary forms, such as poems, short stories, texts, novels, etc. 


\section{RESULTS}

Data collected from the subjects was used in the statistic analyses in order to establish whether personality factors may be the predictors for the undertaking creative activity by young people and if so, to what extent. Two analyses have been carried out. Their aim was to find predictors for the literary activity and activity in other domains of art. The researchers do not agree if creativity is related to sex, however, due to numerous works indicating the potential impact of sex on creativity, this variable was taken into account (Abraham 2016, Abraham et al. 2014, Baer \& Kaufman 2008, Bender et al. 2013, Cheung \& Lau 2010, He \& Wong 2011; Pagnani 2011).

Logistic regression model with the method of backward elimination based on likelihood ratio was applied. The dependent variable was undertaking literary attempts. The analyses were carried out first for women $(\mathrm{N}=288)$, then for men $(\mathrm{N}=69)$. The results of logistic regression for women are presented in Table 2.

The conducted analysis of logistic regression showed that four out of five introduced independent variables are the predictors for undertaking creative literary activity by women. In the final model estimated in five steps, the following variables were included: Conformity-Non-conformity which refers to personality sphere of creative attitude, Potency expressing resourcefulness, firmness, and goal-orientation, Assertiveness which expresses need for authority, high demands and strong will, and Individuality which describes people who are imaginative, unconventional and who have rich imagination.

The goodness of fit by the Hosmer-Lemeshow test is not significant $\left(\chi^{2}=4.225 ; p>0.05\right)$, which means that the obtained model is well fitted to the empirical data. The model explains $12.6 \%$ of the variances of the dependent variable, that is undertaking creative literary activity by women (Nagelkerke's pseudo $\left.\mathrm{R}^{2}=0.126\right)$. The presented model was obtained in Step 2. It enables correct classification of $61.5 \%$ cases.

The variables $\mathrm{K}-\mathrm{N}$ and Individuality were put in the estimated model with positive sign, which means that there is a positive correlation between these variables and the undertaking literary activity by women. The variables Potency and Assertiveness correlated negatively with the literary activation in the model.

It was decided to calculate the odds ratio based on changing the independent variable in the standard deviation in the examined sample. An odds ratio in any given change in predictor value is obtained through multiplication of the size of this change by obtained regression coefficient and increasing the value of Euler's number $(\mathrm{e}=2.71828)$ to the obtained product. Calculated OR(s) indicated how the probability of occurrence of criteria phenomenon will change (increase or decrease) if independent variable value increases by one standard deviation (Danieluk 2010). 
Table 2. The results of logistic regression analysis for women

\begin{tabular}{|c|c|c|c|c|c|c|c|c|}
\hline \multirow{2}{*}{ Step } & \multirow{2}{*}{ Variables } & \multirow{2}{*}{ B } & \multirow{2}{*}{ S.E. } & \multirow{2}{*}{$\begin{array}{l}\text { Wald } \\
(\mathrm{df}=1)\end{array}$} & \multirow{2}{*}{ Sig. } & \multicolumn{3}{|c|}{ 95\% C.I. for $\operatorname{EXP}(B)$} \\
\hline & & & & & & Lower & $\operatorname{Exp}(B)$ & Upper \\
\hline \multirow{6}{*}{ Step 1} & $\mathrm{~K}-\mathrm{N}$ & 0.054 & 0.024 & $5.108^{*}$ & 0.024 & 1.007 & 1.056 & 1.107 \\
\hline & Potency & -0.010 & 0.004 & $7.071 * *$ & 0.008 & 0.982 & 0.990 & 0.997 \\
\hline & Assertiveness & -0.007 & 0.003 & $4.000^{*}$ & 0.045 & 0.986 & 0.993 & 1.000 \\
\hline & Sociability & 0.000 & 0.003 & 0.019 & 0.890 & 0.994 & 1.000 & 1.007 \\
\hline & Individuality & 0.020 & 0.005 & $14.782 * * *$ & 0.000 & 1.010 & 1.021 & 1.031 \\
\hline & Constant & -3.174 & 1.316 & $5.818^{*}$ & 0.016 & & 0.042 & \\
\hline \multirow{5}{*}{ Step 2} & $\mathrm{~K}-\mathrm{N}$ & 0.054 & 0.024 & $5.105^{*}$ & 0.024 & 1.007 & 1.056 & 1.107 \\
\hline & Potency & -0.010 & 0.004 & $7.403^{* *}$ & 0.007 & 0.983 & 0.990 & 0.997 \\
\hline & Assertiveness & -0.007 & 0.003 & $3.987 *$ & 0.046 & 0.987 & 0.993 & 1.000 \\
\hline & Individuality & 0.020 & 0.005 & $15.076^{* * *}$ & 0.000 & 1.010 & 1.020 & 1.031 \\
\hline & Constant & -3.059 & 1.014 & $9.095^{*}$ & 0.003 & & 0.047 & \\
\hline
\end{tabular}

Gender: Female

Note: $\mathrm{R}^{2}=0.095$ (Cox \& Snell); $\mathrm{R}^{2}=0.126$ (Nagelkerke); Hosmer and Lemeshow test $\chi^{2}(8)=4.225 ; \mathrm{p}=0.836$

Model $\chi^{2}(2)=40.483 ; \mathrm{p}<0.001$

Conformity-Non-conformity OR $(\mathrm{s})=1.411 ; \mathrm{s}=6.372$; Potency OR $(\mathrm{s})=0.936 ; \mathrm{s}=6.659$;

Assertiveness OR $(\mathrm{s})=0.722 ; \mathrm{s}=53.029 ;$ Individuality $\mathrm{OR}(\mathrm{s})=2.888 ; \mathrm{s}=36.986$

$* \mathrm{p}<0.05 ; * * \mathrm{p}<0.01 * * * \mathrm{p}<0.001$

Source: Authors' own calculation.

The odds ratio OR(s) for the variable Conformity-Non-conformity is 1.411. In the case of increase in results by one standard deviation, the probability of undertaking literary activity by women increases by almost a half. The calculated odds ratio for the variable Potency $(\mathrm{OR}(\mathrm{s})=0.936)$ shows that when the results within the range of this variable increase by one standard deviation, the probability of undertaking literary activity by women decreases by nearly $10 \%$. If the results in the range on the scale Assertiveness increase by one standard deviation, the probability of undertaking literary activity by women decreases by about $30 \%(\mathrm{OR}(\mathrm{s})=0.722)$. This indicator should be interpreted very carefully because of high standard deviation of this variable in relation to the mean $(\mathrm{M}=96.181$; $\mathrm{SD}=53.029)$. The odds ratio for the variable Individuality is 2.888 , which means that increase in results in the range of this variable by one standard deviation increases the probability of undertaking literary activity by women almost three times. 
The results of analysis of logistic regression presented in Table 3 showed that there are two predictors for the undertaking literary activity among men (from five introduced in the model). In the final model obtained in the course of estimation, the following were included: the scale Conformity-Non-conformity (concerning personality aspects of creative attitude) and the variable Assertiveness which is one of six factors found on the basis of factor analysis in ACL. This factor expresses strong will, need for authority and having high demands. The obtained model is well fitted to data which is confirmed by not significant goodness of fit (the Hosmer-Lemeshow test $\left(\chi^{2}=10.145 ; p>0.05\right)$ ). This model explains $11 \%$ of the variance of the dependent variable, that is undertaking literary activity by men (Nagelkerke's pseudo $\mathrm{R}^{2}=0.110$ ). Presented model was estimated in Step 4 and enables accurate classification of $65.2 \%$ cases.

The values of partial correlation $(\beta)$ for the variable conformism-non-conformism are negative, which means that this variable has a negative predictive power for predicting the probability of undertaking literary activity by men. The value $\beta$ for the variable Assertiveness has a positive sign which means that the variable has a positive predictive power in the proposed model.

Table 3. The results of logistic regression analysis for men

\begin{tabular}{|c|c|c|c|c|c|c|c|c|}
\hline \multirow{2}{*}{ Step } & \multirow{2}{*}{ Variables } & \multirow{2}{*}{ B } & \multirow{2}{*}{ S.E. } & \multirow{2}{*}{$\begin{array}{l}\text { Wald } \\
(\mathrm{df}=1)\end{array}$} & \multirow{2}{*}{ Sig. } & \multicolumn{3}{|c|}{ 95\% C.I. for $\operatorname{EXP(B)}$} \\
\hline & & & & & & Lower & $\operatorname{Exp}(B)$ & Upper \\
\hline \multirow{6}{*}{ Step 1} & $\mathrm{~K}-\mathrm{N}$ & -0.136 & 0.060 & $5.114 *$ & 0.024 & 0.776 & 0.873 & 0.982 \\
\hline & Potency & -0.002 & 0.007 & 0.099 & 0.753 & 0.983 & 0.998 & 1.012 \\
\hline & Assertiveness & 0.007 & 0.007 & 0.817 & 0.366 & 0.992 & 1.007 & 1.022 \\
\hline & Sociability & 0.011 & 0.008 & 1.897 & 0.168 & 0.996 & 1.011 & 1.026 \\
\hline & Individuality & 0.013 & 0.014 & 0.866 & 0.352 & 0.985 & 1.013 & 1.042 \\
\hline & Constant & -0.933 & 3.587 & 0.068 & 0.795 & & 0.393 & \\
\hline \multirow{3}{*}{ Step 4} & $\mathrm{~K}-\mathrm{N}$ & -0.128 & 0.057 & $5.061 *$ & 0.024 & 0.787 & 0.880 & 0.984 \\
\hline & Assertiveness & 0.010 & 0.006 & 3.099 & 0.078 & 0.999 & 1.010 & 1.022 \\
\hline & Constant & 3.585 & 1.656 & $4.690^{*}$ & 0.030 & & 36.067 & \\
\hline
\end{tabular}

Gender: Male

Note: $\mathrm{R}^{2}=0.82$ (Cox \& Snell); $\mathrm{R}^{2}=0.110$ (Nagelkerke); Hosmer and Lemeshow

test $\chi^{2}(8)=10.145 ; \mathrm{p}=0.255$

Model $\chi^{2}(2)=5.930 ; p=0.052$.

Conformity-Non-conformity OR(s) $=0.483 ; \mathrm{s}=5.692$; Assertiveness OR(s) = 1.742;

$\mathrm{s}=53.800$

$* \mathrm{p}<0.05$

Source: Authors' own calculation. 
As to Conformity-Non-conformity on the basis of the odds ratio $(\mathrm{OR}(\mathrm{s})=0.483)$, it can be predicted that increase in results on this scale by one standard deviation decreases by more than half the chance of undertaking creative literary activity among men. The next variable, that is Assertiveness, was shown as to be a predictor of high significance and power. The calculated odds ratio $\mathrm{OR}(\mathrm{s})$ is 1.742 and implies that increase of results in this scale by one standard deviation causes increase in chance of undertaking creative literary activity by nearly $75 \%$. It is of importance here to note that standard deviation for this variable in the group of men with relation to the medium is very high $(\mathrm{M}=79.608$; $\mathrm{SD}=53.800$ ), which is important for interpretation of this indicator.

\section{DISCUSSION}

The presented research enabled finding personality predictors for undertaking literary activity by women and men in early adulthood. Personality traits which predict the probability of undertaking literary attempts in women are Non-conformity, Individualism, low Potency and low Assertiveness, while in men - Conformity and Assertiveness.

The strongest predictors explaining the undertaking artistic activity by young women are Non-conformity and Individualism. Those results correspond with the conclusions drawn from other works. Individuality is a factor expressing Independence, Non-conformity and Unconventionality. Those characteristics correspond with the description of the factor independence, the characteristic of a creative person in Nęcka's model of creative personality. Independence is manifested in the non-conformist attitude, not yielding to pressure and autonomy. Furthermore, this trait is strongly connected with psychoticism understood - according to Eysenck's model of personality - as the tendency to breaking rules, challenging authority and questioning norms (Nęcka 2012). Eysenck himself pointed out connections between psychoticism and creativity (Eysenck 1994). The factor Individualism describes also people sensitive in terms of aesthetics, with aesthetic interests, open and full of ideas. This characteristic fully corresponds with Piirto's research results. She demonstrated that the creative writers are independent and non-conformist, they appreciate aesthetic, ethical and intellectual values, are sensitive in terms of aesthetics (Piirto 2002). Individualism also includes openness. The relationship between this trait and creativity have been confirmed by numerous findings (Batey et al. 2009, Chamorro-Premuzic \& Reichenbache 2008, Furnham \& Bachtiar 2008, Furnham et al. 2009, Greengross \& Miller 2009, Kaufman 2002, Kaufman et al. 2015, Nusbaum \& Silvia 2011, Piirto 2002, Silvia et al. 2009). Both independence and persistence are the main of three traits proposed in Nęcka's model of creative personality (Nęcka 2012). 
The factors which have negative predictive power for literary activity are Potency and Assertiveness. It was demonstrated that higher probability of undertaking literary activity among young adults is related to personality traits such as being disorganised and undisciplined, with low efficiency, not goal-oriented and not focused on succeeding. There is no clear confirmation of these results. In Strzałecki's model, the Strong Ego is one of the components of creative behaviour (Strzałecki 2003, 2011). In his most recent works, this author also implies the existence of the General Factor of Creative Personality. This general factor is a manifestation of overall personality competence connected with the ability to formulate long-distance goals and stability that is necessary in achieving those goals (Strzałecki 2012). It should be noted that Strzałecki's research was focused mostly on entrepreneurs, which means that the personality structure proposed by him is characteristic of representatives of the specific domain - entrepreneurship. The discussed and presented results in the current study might suggest that creative artists differ in personality from businessmen.

Negative predictive power in explaining undertaking literary activity by women in early adulthood also had the factor Assertiveness. The results of present research showed that higher probability of undertaking creative literary activity is characteristic of women of calm nature, who do not want to draw attention, are quiet, withdrawn, subordinate to others, timid and lacking faith in their own abilities. This factor appears to be close to Agreeableness form the Big Five model and Honesty-Humility from the HEXACO model, which are connected with creativity. However, the results of the study indicate the different relationships than those suggested by other researchers' works (Silvia et al. 2011). Assertiveness is defined for the purpose of this research as to be strictly connected with achievement motivation. It shows that the motivational mechanism of young women who are literary creative has a different character. Probably in young women autonomous motivation predominates. It enables achieving satisfaction from the pure creative process and not only from the achieved successes. This type of motivation in a creative process is equally important as the achievement motivation (Nęcka 2012).

The factors which explain undertaking creative literary activity by young men are assertiveness and conformist attitude. The presented results showed that literary activity is undertaken by men who trust themselves, are sure of their abilities, like to be in the centre of attention, are domineering, and craving authority. This characteristic shows many traits shared with the low pole of the Honesty-Humility dimension in the HEXACO model. Those results confirmed the results of Silvia's research which showed that between creativity and Honesty-Humility there is an inversely proportional relationship (Silvia et al. 2011). These characteristics also indicate the strong achievement motivation and persistence mentioned by Nęcka when describing creative personality (Nęcka 2012). 
The level of Non-conformity has a negative predictive power in explaining undertaking literary activity by young men. This means that literary activity is more often undertaken by stereotypical, dependent, passive, weak, and adaptively rigid men. These results contradict other authors' findings which point out that creativity is connected with Non-conformity, independence and originality (Nęcka 2012, Piirto 2002).

\section{CONCLUSIONS}

The presented research enabled finding personality predictors for the undertaking artistic activity. It was shown that the undertaking literary activity by young women is related with high level of Non-conformity and Individuality, and low level of Potency and Assertiveness. Literary activity is undertaken by women who are independent, original, spontaneous, self-reliant and self-critical, characterised by high openness and aesthetic sensitivity, but also quiet, withdrawn, calm, with prevalence of autonomous motivation over achievement motivation. The undertaking literary activity by men is predicted differently. Literary activity is undertaken by men who like being in the centre of attention, are self-confident, sure of their abilities and crave authority but also are conformist - stiff, with low immunity and persistence, not independent, weak, and timid.

This research revealed the particularly interesting configurations of Conformity and traits indicating Assertiveness and Potency. It is depending on sex which suggests the differences between sexes in the way of manifesting Non-conformity and different ways of socialization for girls and boys. Non-conformist women and individualists who are not strong and not assertive, aim at achieving successes and achieving highly positioned goals, may express their own Non-conformity and Individualism by undertaking the literary activity. However, this activity corresponds with the stereotype of femininity, including traits such as emotionality, sensitivity, empathy or submission (Brannon 2002). Young men who are characterized by high assertiveness, self-confidence, have strong will and need for authority, engage in the literary activity only if they manifest conformist traits. It may stem from the fact that assertive non-conformists will engage in those activities which might bring success, high social status or authority. Such activities let them get high achievement motivation. This is in accordance with the stereotype of masculinity including traits such as domination, pursuing goals, independence, rationality and being effective in action (Brannon 2002).

The presented results showed the different motivational mechanisms in men and in women related to the literary activation. It clearly demonstrated that personality traits are important predictors for the literary activity, however, in a different way in young men and women. 


\section{BIBLIOGRAPHY}

Abraham A. (2016), Gender and creativity: an overview of psychological and neuroscientific literature, "Brain Imaging and Behavior",10 (2), 609-618.

Abraham A., Thybusch K., Pieritz K., Hermann C. (2014), Gender differences in creative thinking: behavioral and fMRI findings, "Brain Imaging and Behavior", 8 (1), 39-51.

Ashton M.C., Lee K. (2001), A theoretical basis for the major dimensions of personality, "European Journal of Personality", 15 (5), 327-353.

Ashton M.C., Lee, K. (2005), Honesty-Humility, the Big Five, and the Five-Factor Model, "Journal of Personality", 73 (5), 1321-1354.

Ashton M.C., Lee K. (2007), Empirical, theoretical, and practical advantages of the HEXACO model of personality structure, "Personality and Social Psychology Review", 11 (2), 150-166.

Baer J., Kaufman J.C. (2008), Gender differences in creativity, "The Journal of Creative Behavior", $42(2), 75-105$.

Baer J., Kaufman J., Sternberg R. (2010), Is creativity domain specific, [in:] J. Kaufman, R. Sternberg (eds.), The Cambridge Handbook of Creativity, New York: Cambridge University Press, 75-105.

Batey M., Chamorro-Premuzic T., Furnham A. (2009), Intelligence and personality as predictors of divergent thinking: The role of general, fluid and crystallised intelligence, "Thinking Skills and Creativity", 4 (1), 60-69.

Batey M., Furnham A., Safiullina X. (2010), Intelligence, general knowledge and personality as predictors of creativity, "Learning and Individual Differences", 20 (5), 532-535.

Bender S.W. Nibbelink B., Towner-Thyrum E., Vredenburg D. (2013), Defining characteristics of creative women, "Creativity Research Journal", 25 (1), 38-47.

Bernacka R.E. (2009), KANH III Questionnaire of Creative Behaviour-presentation of the revised version, [in:] S. Popek, R.E. Bernacka., C. Domański, B. Gawda, D. Turska, A. Zawadzka (eds.), Psychologia twórczości. Nowehoryzonty. Psychology of creativity. New approaches, Lublin: UMCS, 169-175.

Brannon L. (2002), Psychologia rodzaju. Kobiety i mężczyźni: podobni czy różni, Gdańsk: GWP.

Chamorro-Premuzic T., Reichenbacher L. (2008), Effects of personality and threat of evaluation on divergent and convergent thinking, "Journal of Research in Personality", 42 (4), 1095-1101.

Cheung P.C., Lau S. (2010), Gender differences in the creativity of Hong Kong school children: Comparison by using the new electronic Wallach-Kogan creativity tests, "Creativity Research Journal", 22 (2), 194-199.

Danieluk B. (2010), Zastosowanie regresji logistycznej w badaniach eksperymentalnych, "Psychologia Społeczna", 2-3 (14), 199-217.

DeYoung C.G., Peterson J.B., Higgins D.M. (2002), Higher-order factors of the Big Five predict conformity: Are there neuroses of health?, "Personality and Individual Differences", 33 (4), $533-552$.

Digman J.M. (1997), Higher-order factors of the Big Five, "Journal of Personality and Social Psychology", 73 (6), 1246-1256.

Eysenck H.J. (1994), Creativity and personality: Word association, origence, and psychoticism, "Creativity Research Journal", 7 (2), 209-216.

Furnham A., Bachtiar V. (2008), Personality and intelligence as predictors of creativity, "Personality and Individual Differences", 45 (7), 613-617.

Furnham A., Crump J., Batey M., Chamorro-Premuzic T. (2009), Personality and ability predictors of the "consequences" test of divergent thinking in a large non-student sample, "Personality and Individual Differences", 46 (4), 536-540. 
Greengross G., Miller G.F. (2009), The Big Five personality traits of professional comedians compared to amateur comedians, comedy writers, and college students, "Personality and Individual Differences", 47 (2), 79-83.

Han K.S., Marvin C. (2002), Multiple Creativities? Investigating Domain-Specificity of Creativity in Young Children, "Gifted Child Quarterly", 46 (2), 98-109.

He W., Wong W. (2011), Gender differences in creative thinking revisited: Findings from analysis of variability, "Personality and Individual Differences", 51 (7), 807-811.

Jamison K.R. (1996), Touched with Fire: Manic-Depressive Illness and the Artistic Temperament, New York: Simon and Schuster.

Kaufman J.C. (2000), Genius, lunatics and poets: Mental illness in prize-winning authors, "Imagination, Cognition and Personality", 20 (4), 305-314.

Kaufman J.C. (2001), The Sylvia Plath effect: Mental illness in eminent creative writers, "The Journal of Creative Behavior", 35 (1), 37-50

Kaufman J.C. (2002), Narrative and Paradigmatic Thinking Styles in Creative Writing and Journalism Students, "Journal of Creative Behavior", 36 (3), 201-220.

Kaufman J.C. (2003), The cost of the muse; poets die young, "Death Studies”, 27 (9), 813-821.

Kaufman J.C. (2012), Counting the muses: Development of the Kaufman Domains of Creativity Scale (K-DOCS), "Psychology of Aesthetics, Creativity, and the Arts", 6 (4), 298-308.

Kaufman J.C., Baer J. (2002), I bask in dreams of suicide: Mental illness, poetry, and women, "Review of General Psychology", 6 (3), 271-286.

Kaufman J.C., Sexton J.D. (2006), Why doesn't the writing cure help poets?, "Review of General Psychology", 10 (3), 268-292.

Kaufman S.B., Quilty L.C., Grazioplene R.G., Hirsh J.B., Gray J.R., Peterson J.B., DeYoung C G. (2015), Openness to experience and intellect differentially predict creative achievement in the arts and sciences, "Journal of Personality", 82, 248-258.

Kohanyi A. (2005), Four factors that may predict the emergence of creative writing: A proposed model, "Creativity Research Journal", 17 (2-3), 195-205.

Lee K., Ashton M.C. (2004), Psychometric properties of the HEXACO personality inventory, "Multivariate Behavioral Research", 39 (2), 329-358.

Ludwig A.M. (1994), Mental illness and creative activity in female writers, "American Journal of Psychiatry", 151 (11), 1650-1656.

Ludwig A.M. (1995), The price of greatness: Resolving the creativity and madness controversy, New York: Guilford Press.

Martowska K. (2012), Lista przymiotnikowa ACL: Harrison G. Gough, Alfred B. Heilbrun, Jr. Polska normalizacja, Warszawa: Pracownia Testów Psychologicznych PTP.

McCrae R.R., Costa P.T. (2008), Empirical and theoretical status of the five-factor model of personality traits, [in:] G.J. Boyle, G. Matthews, D.H. Saklofske (eds.), The SAGE Handbook of Personality Theory and Assessment, 1, Thousand Oaks, CA: SAGE Publications Ltd, 273-294.

Nęcka E. (2012), Psychologia twórczości, Gdańsk: GWP.

Nettle D. (2006), Schizotypy and mental health amongst poets, visual artists, and mathematicians, "Journal of Research in Personality", 40 (6), 876-890.

Nusbaum E.C., Silvia P.J. (2011), Are openness and intellect distinct aspects of openness to experience? A test of the O/I model, "Personality and Individual Differences", 51 (5), 571-574.

Pagnani A.R. (2011), Gender differences, [in:] M.A. Runco, S.R. Pritzker (eds.), Encyclopedia of Creativity, San Diego: Academic, 551-557.

Park G., Lubinski D., Benbow C.P. (2007), Contrasting intellectual patterns predict creativity in the arts and sciences tracking intellectually precocious youth over 25 years, "Psychological Science", 18 (11), 948-952.

Piirto J. (1998), Themes in the lives of successful contemporary U.S. women creative writers, "Roeper Review: A Journal on Gifted Education", 21 (1), 60-70. 
Piirto J. (2002), My teeming brain: Understanding creative writers, Cresskill: Hampton Press.

Piirto J. (2004), Understanding Creativity, Scottsdale, Arizona: Great Potential Press.

Piirto J. (2010), 21 years with the Dabrowski theory: An autoethnography, "Advanced Development Journal”, 12, 68-90.

Plucker J.A. (1999), Reanalyses of student responses to creativity checklists: Evidence of content generality, "The Journal of Creative Behavior", 33 (2), 126-137.

Popek S. (2001), Człowiek jako jednostkatwórcza, Lublin: UMCS.

Popek S. (2010), Psychologia twórczości plastycznej, Kraków: Impuls.

Preti A., Miotto P. (1999), Suicide among eminent artists, "Psychological Reports", 84 (1), 291-301.

Silvia P.J., Kaufman J.C. (2010), Creativity and mental illness, [in:] J.C. Kaufman, R.J. Sternberg (eds.), The Cambridge Handbook of Creativity, New York: Cambridge University Press, 381394.

Silvia P.J., Kaufman J.C., Pretz J.E. (2009), Is creativity domain-specific? Latent class models of creative accomplishments and creative self-descriptions, "Psychology of Aesthetics, Creativity, and the Arts", 3 (3), 139-148.

Silvia P.J., Kaufman J.C., Reiter-Palmon R., Wigert B. (2011), Cantankerous creativity: HonestyHumility, Agreeableness, and the HEXACO structure of creative achievement, "Personality and Individual Differences", 51 (5), 687-689.

Silvia P.J., Nusbaum E C., Berg C., Martin C., O'Connor A. (2009), Openness to experience, plasticity, and creativity: Exploring lower-order, high-order, and interactive effects, "Journal of Research in Personality", 43 (6), 1087-1090.

Strus W., Cieciuch J. (2014), Poza Wielka Piątkę - przegląd nowych modeli struktury osobowości, "Polskie Forum Psychologiczne", 19 (1), 17-49.

Strzałecki A. (2003), Psychologia twórczości: między tradycja a ponowoczesnością, Warszawa: UKSW.

Strzałecki A. (2011), Styl Twórczego Zachowania. Model i jego walidacja, [in:] W. Zeidler (ed.), Kwestionariusze w psychologii. Postepy, zastosowania, problemy, Warszawa: Wydawnictwo Vizja Press \& IT, 190-244.

Strzałecki A. (2012), Sprawność osobowości. Kontrowersje wokół ogólnego czynnika osobowości twórczej, "Zagadnienia Naukoznawstwa", 2 (48), 85-109.

\section{STRESZCZENIE}

Celem niniejszej pracy jest odnalezienie osobowościowych predyktorów podejmowania twórczości literackiej w okresie wczesnej dorosłości. Do analizy włączono wyniki łącznie 357 osób. Około połowa z nich podejmuje aktywność literacką, czyli pisze wiersze, opowiadania, powieści. Do pomiaru cech osobowości potencjalnie związanych z osobowością twórczą wykorzystano dwa kwestionariusze osobowości (ACL, KANH-III). Aby odnaleźć osobowościowe predyktory podejmowania twórczości literackiej, przeprowadzono regresję logistyczną. Zmienna zależna miała charakter binarny (aktywność literacka vs brak aktywności literackiej), zmiennymi niezależnymi były: siła, asertywność, towarzyskość, indywidualizm (ACL) oraz konformizm-nonkonformizm (KANH). Wyniki pokazały, że istotnymi predyktorami podejmowania twórczości literackiej przez kobiety są: wysoki poziom nonkonformizmu oraz indywidualizmu, a także niski poziom siły i asertywności. Istotnymi predyktorami podejmowania twórczości literackiej przez mężczyzn są wysoki poziom konformizmu oraz wysoki poziom asertywności.

Słowa kluczowe: osobowość; kreatywność; twórczość literacka 